\begin{tabular}{|c|c|c|}
\hline & \multirow{2}{*}{$\begin{array}{c}\text { International Journal of Current Research in } \\
\text { Biosciences and Plant Biology } \\
\text { Volume } 7 \text { • Number } 10 \text { (October-2020) • ISSN: } 2349-8080 \text { (Online) }\end{array}$} & $=$ \\
\hline & & \\
\hline $\begin{array}{l}\text { EXCELLENT } \\
\text { PUBLISHERS }\end{array}$ & Journal homepage: www.ijcrbp.com & \\
\hline
\end{tabular}

\title{
Response of three tossa jute (Corchorus olitorius L.) cultivars produced in Benin to salinity stress at germination and young plant stages
}

\author{
Belvida Loko', Koffi David Hambada Montcho², Armel Clément Goudjo Mensah3, \\ Mahougnon Baudouin Geoffroy Gouveitcha', Agapit Wouyou', Julien Koffi \\ Kpinkoun', Françoise Assogba Komlan'3, Christophe Bernard Gandonou1*
}

\begin{abstract}
${ }^{1}$ Unité de Recherche sur l'Adaptation des Plantes aux Stress Abiotiques, les Métabolites Secondaires et l'Amélioration des
Productions Végétales, Laboratoire de Physiologie Végétale et d'Etude des Stress Environnementaux,

Faculté des Sciences et Techniques (FAST/UAC), 01BP526, Tri Postal, Cotonou, République du Bénin ${ }^{2}$ Ecole de Gestion et de Production Végétale et Semencière, Université Nationale d'Agriculture, République du Bénin 3 Centre de Recherches Agricoles Plantes Pérennes (CRA-PP), Pobè, Institut National des Recherches Agricoles du Bénin (INRAB), Abomey-Calavi, République du Bénin
\end{abstract}

*Corresponding author; e-mail: ganchrist@hotmail.com

\begin{tabular}{|c|c|}
\hline Arti & ABSTRACT \\
\hline $\begin{array}{l}\text { Date of Publication: } \\
06 \text { October } 2020\end{array}$ & \multirow{3}{*}{$\begin{array}{l}\text { The response of three tossa jute cultivars Ordinaire, } 5 \text {-Doigts and Acc : Sud } 2 \text { to salt } \\
\text { stress was evaluated at germination and young plant stages. Five NaCl concentrations: } \\
\text { o; } 30 ; 60 ; 90 \text { and } 120 \mathrm{mM} \text { NaCl were used. Seeds were submitted to NaCl in petri } \\
\text { dishes and germination was checked every day during thirty days in a completely } \\
\text { randomized design with four replicates. Four-week old plants were submitted in pots to } \\
\text { the same five NaCl concentrations by irrigation every two days for two weeks in screen } \\
\text { house. NaCl reduced seed germination rate in all cultivars from day } 2 \text { to day } 30 \text { and the } \\
\text { germination index. At the end of the } 30 \text { days, salt stress reduced the final germination } \\
\text { percentages with a significant difference among cultivars: cultivar } 5 \text {-doigts was the least } \\
\text { affected than the two other cultivars. Salt effect caused a reduction of young plant } \\
\text { growth whatever the growth parameter considered with a significant difference among } \\
\text { cultivars. The growth of cultivar Acc:Sud } 2 \text { was more affected by salt stress with the } \\
\text { lowest salt tolerance index whereas that of cultivar Ordinaire was the least affected } \\
\text { with the highest salt tolerance index. Thus, cultivar 5-Doigts appeared as the most } \\
\text { resistant to salt stress at germination stage among the three cultivars; whereas cultivar } \\
\text { Ordinaire followed by 5-Doigts was the most salt resistant at young plant stage. }\end{array}$} \\
\hline Кеу & \\
\hline & \\
\hline
\end{tabular}

\section{Introduction}

Salinity is one of the most important environmental constraints limiting the agricultural productivity around the world (Ashraf et al., 2004;
Hussain et al., 2004). On average, the world loses 10 hectares of cultivable land per minute, including 3 hectares due to salinization (Mermoud, 2006). In fact, the salinity covers more than $6 \%$ of the total surface of the planet, $3.8 \%$ of which is located in 
Africa (Manchanda, 2008). In Benin, the extent of land affected by salinity is not precisely known. However, preliminary studies (unpublished) carried out by our research team with our partners have shown that certain vegetable production areas including non-coastal areas are at high salt risk. Indeed, the degree of plant response to salinity depends on salt concentration, plant species, variety and development stage (Bennaceur et al., 2001). Germination is considered as one of the most critical stages in the life cycle of plants (Almansouri et al., 2001; Hadas, 2004). In addition, under salt stress conditions, seed germination and the first phase of seedling growth are critical stages for plant establishment (Khan et al., 2003). The response of plants to increased $\mathrm{NaCl}$ concentration depends on the species (Lakra, 2006; Chukwu et al., 2006; Gandonou et al., 2012). In addition, within the same given species, a substantial variation in salt sensitivity may appear in cultivars or varieties as it has been reported in several species of vegetable crops including amaranth (Wouyou et al., 2016) ; chili (Kpinkoun et al., 2018), cabbage (Gouveitcha et al., 2020) and tomato (Kinsou et al., 2019; 2020).

Two species of jute Corchorus capsularis L. (Deshi jute) and Corchorus olitorius L. (Tossa jute) are grown in tropical and subtropical regions for trade purposes (Edmonds, 1990). In Benin, tossa jute (Corchorus olitorius L.), commonly known as "crincrin" holds an important position in people's diet and is one of the most widely practiced market gardening crops (Savi, 2009). Due to the richness of its tender leaves in nutritional substances (vitamin C, provitamin A, mineral salts, proteins), Corchorus olitorius also known as wild okra (Ahmadi et al., 2016) could be a "powerful weapon" to combat nutritional deficiencies, especially in developing countries (Kahane et al., 2005; Soro et al., 2012). Market gardeners in Southern Benin acknowledge the salinity of irrigation water and sea spray as a major problem for their activities (Orobiyi et al., 2013; Déguénon, 2018 cited by Kpinkoun, 2019). Much of the jute production area in Benin is located in the coastal zone and irrigated lands in Southern Benin where soil and irrigation water salinity are real problems hampering crop production. The identification of salt resistant genotypes capable of minimizing the depressive effects of salinity on yields would certainly improve agricultural production in areas affected by salinity. Some studies were focused on the effect of salt stress on jute seed germination and plant growth. Among them, we can quote Khandker et al. (1992), Islam et al. (2011), Ahmadi et al. (2015) and Ben Yakoub et al. (2019). However, except the works of Ghosh et al. (2013) and Naik et al. (2015), data on salinity tolerance of tossa jute cultivars/varieties are rare. Moreover, basically no research work has focused on salt resistance of tossa jute cultivars produced in Benin. The current study is designed to fill this gap. It mostly aims at evaluating the relative level of salt resistance of tossa jute cultivars available in Benin at both germination and young plant stages.

\section{Materials and methods}

\section{Plant material}

Three tossa jute cultivars including two local (Ordinaire and 5-Doigts) and one introduced (Acc:Sud 2) were used. Seeds of cultivars Ordinaire and 5-Doigts were provided by the National Institute of Agricultural Research of Benin (INRAB) whereas those of the introduced cultivar were provided by World Vegetable Center (WVC).

\section{Experimental conditions}

For germination stage study, the experiment was laid out as a Completely Randomized Design (CRD) with four replications. Seeds (40) of each cultivar were incubated in $10 \mathrm{~cm}$ Petri dishes on one layer of filter paper moistened with $15 \mathrm{ml}$ distilled water (control) and the same volume of salt solutions of $0 ; 30 ; 60 ; 90$ or $120 \mathrm{mM} \mathrm{NaCl}$. Seeds were incubated in darkness at $26^{\circ} \mathrm{C}$. The seed was considered as germinated when the radicle emerged from the seed coat and germination was checked every two days during thirty days incubation period.

For young plant stage study, the experiment was carried out in a screen house at Center of Agricultural Research of Agonkanmey (AbomeyCalavi, Republic of Benin) from June to August 2019. Plants were cultivated at a temperature of 26 ${ }^{\circ} \mathrm{C} / 22$ day/night with natural light and a relative humidity of $55 \%$. Seeds underwent a dormancy break before germination in trays filled with potting soil for three weeks. Young seedlings were 
then transferred to earthen small pots of $5.8 \mathrm{~cm}$ diameter and $6 \mathrm{~cm}$ height containing a mixture of potting soil and sandy loam soil 50:50 (one plant/pot) and cultivated for one week before stress application. Plants of the three cultivars were submitted to salt stress in earthen big pots of $11.3 \mathrm{~cm}$ diameter and $14 \mathrm{~cm}$ height filled with $3 \mathrm{~kg}$ of a same mixture. Treatments consisted of plant irrigation every two days with $100 \mathrm{ml} /$ pot of salt solution of $0 ; 30 ; 60 ; 90$ or $120 \mathrm{mM} \mathrm{NaCl}$ corresponding respectively to an electric conductivity of $0.221 ; 3.827 ; 6.47 ; 10.56$ and 14.02 $\mathrm{dS} . \mathrm{m}^{-1}$ determined by a conductimeter (VWR; CO310). The experiment was laid out as a Completely Randomized Design (CRD) with two factors and four replications. The two considered factors were cultivars (with three levels) and salt concentrations (with five levels).

\section{Experiment evaluation}

Salt effect on seed germination was evaluated using germination kinetics, germination index and final germination percentage. The germination index was calculated according to Wouyou et al. (2016) ; Kpinkoun et al. (2018) and Gouveitcha et al. (2020) as Germination Index (GI) $=10 \times(n 24+$ $n 48+n 72) /(n 24+2 n 48+3 n 72)$ where $n 24, n 48$, $n 72$ were respectively the number of germinated seeds on 24,48 , et 72 hours.

Plant height, leaf number, root length, shoot and root fresh and dry matters were measured before stress application (Xo); they were measured again after 2 weeks of treatment (X1). For dry matter determination, fresh samples were transferred to an oven at $80{ }^{\circ} \mathrm{C}$ for 72 hours. Plants Relative Growth was calculated for each growth parameter as (X1- Xo)/ Xo.

Cultivars were determined according to their salt resistance using the following parameters:

- the final germination percentage reduction under salt stress;

- the growth reduction under salt stress;

- the Salt Tolerance Index (STI) calculated according to Tabatabaei et al. (2012) either for seed germination (based on final germination percentage) or for plant growth as:
Salt Tolerance Index $(\mathrm{STI})=\left(\mathrm{Y}_{\mathrm{S}} \times \mathrm{Y}_{\mathrm{P}}\right) /(\overline{\mathrm{Y}} \mathrm{p})^{2}$ where,

Ys $=$ measure of one replicate under $\mathrm{NaCl}$ treatment.

$\mathrm{Yp}=$ measure of one replicate of the control.

$\bar{Y} \mathrm{p}=$ means of measures of all replicates of the control.

\section{Statistical analysis}

For all parameters, each value was presented in the form of mean \pm standard error with a reading of four independent samples per treatment. The analysis of the main effects of stress intensity or cultivars was based on a one-way analysis of variance (ANOVA). Means were compared with Tukey-Kramer test. Data were statistically analyzed using the JMP Pro 12" software (SAS Institute, 2015).

\section{Results}

\section{Effect of salt stress on seed germination}

Figs. 1, 2, and 3 show the evolution of seed germination as a function of time from 2 to 30 days of germination in the presence of $\mathrm{NaCl}$ at $0 ; 30$; 60; 90; and $120 \mathrm{mM}$ respectively for the cultivars Ordinaire, 5-Doigts and Acc: Sud 2. In the absence of stress, the responses of the three jute cultivars were different from the second $\left(2^{\text {nd }}\right)$ day until the thirtieth $\left(30^{\text {th }}\right)$ germination day. After two days, more than $70 \%$ of the seeds germinated for the cultivars Ordinaire $(75.62 \%)$ and 5-Doigts (74.37\%) while less than $5 \%$ of the seeds germinated for the cultivar Acc: Sud 2 (1.87\%). Thus, seed germination began from day 2 in the absence of stress for all cultivars. By day 4, the percentage of germination increased in all cultivars and reached $78.75 \%$ for Ordinaire; $78.12 \%$ for $5^{-}$ Doigts and $4.37 \%$ for Acc: Sud 2. Thus, the percentage of seed germination was greater than $75 \%$ for all jute cultivars after 4 days except cultivar Acc: Sud 2 (4.37\%). After 4 days, no change was observed in the germination percentage of cultivar 5-Doigts indicating that this cultivar reached its maximum germination capacity after 4 days. For the other two cultivars, the germination percentage increased slowly until the 3oth day corresponding to the end of the experiment, reaching $83.75 \%$ for the cultivar Ordinaire and 55\% for Acc: Sud 2. These results 
revealed a significant variability in the germination capacity of cultivars in the absence of stress. Cultivar Ordinaire exhibited the greatest germination capacity while Acc: Sud 2 showed the lowest. In the presence of $\mathrm{NaCl}$, there was a slowdown in germination for all cultivars and all concentrations from the second $\left(2^{\text {nd }}\right)$ to the thirtieth $\left(30^{\text {th }}\right)$ day of germination with reactions that vary among cultivars (Fig. 1, 2 and 3): On the second $\left(2^{\text {nd }}\right)$ day, germination percentages decreased in Ordinaire with reductions of $3.12 \%$; $4.37 \% ; 37.5 \%$ and $71.25 \%$ relative to the control respectively at 30; 60; 90 and $120 \mathrm{mM} \mathrm{NaCl}$. For 5Doigts, germination percentages decreased with reductions of $7.5 \% ; 10 \% ; 40 \%$ and $64.37 \%$ relative to the control respectively at 30; 60; 90 and 120 $\mathrm{mM} \mathrm{NaCl}$. For Acc: Sud 2, there was also a reduction corresponding to $0.62 \% ; 1.87 \% ; 1.87 \%$; $1.87 \%$ respectively at $30 ; 60 ; 90$ and $120 \mathrm{mM} \mathrm{NaCl}$. At 60; 90 and $120 \mathrm{mM} \mathrm{NaCl}$, no seed of cultivar Acc: Sud 2 germinated. On the fourth day, germination percentages decreased in Ordinaire with reductions of $3.12 \% ; 3.75 \% ; 33.12 \%$ and $70.62 \%$ relative to the control; for 5 -Doigts the reduction rates were 5\%; $9.37 \% ; 38.75 \%$ and 63.12\% compared to the control and for Acc: Sud 2 , the reduction rates were $2.5 \% ; 3.73 \%$ and $4.37 \%$ respectively at 30;60; 90 and $120 \mathrm{mM} \mathrm{NaCl}$. At 90 and $120 \mathrm{mM} \mathrm{NaCl}$, no seeds germinated for Acc: Sud 2. Similar observations were made from the $6^{\text {th }}$ to the $30^{\text {th }}$ day except that for the cultivar Ordinaire from the $14^{\text {th }}$ to the $30^{\text {th }}$ day. There was a slight increase in the germination percentage at $120 \mathrm{mM} \mathrm{NaCl}$ versus $90 \mathrm{mM} \mathrm{NaCl}$ and from day 26 to day 28 this increase was observed at $60 \mathrm{mM}$ versus $30 \mathrm{mM} \mathrm{NaCl}$ in Ordinaire. In 5 -Doigts, a slight increase was observed at $60 \mathrm{mM} \mathrm{NaCl}$ compared to $30 \mathrm{mM} \mathrm{NaCl}$ and even compared to the control (o mM NaCl) from the $26^{\text {th }}$ to the $30^{\text {th }}$ day). For cultivar Acc: Sud 2, germination started for the high concentrations $(60,90$ and 120$) \mathrm{mM}$ of $\mathrm{NaCl}$ respectively from only the $4^{\text {th }}, 6^{\text {th }}$ and $12^{\text {th }}$ day. This result showed that stress delayed seed germination of all jute cultivars with varying reactions depending on the cultivar. The germination delay was more noted in cultivar Acc: Sud 2 compared to the other two cultivars.

Table 1 shows the effect of $\mathrm{NaCl}$ on germination index of the three cultivars of horsehair. In the absence of stress, the Germination Indexes (GI) of the three cultivars were $8.78 ; 9.047$ and 2.50 respectively for Ordinaire, 5-Doigts and Acc: Sud 2. Cultivar 5-Doigts had the highest germination index while Acc: Sud 2 had the lowest. The effect of $\mathrm{NaCl}$ caused a reduction in the germination index in all cultivars tested. However, the three cultivars showed variable responses. Cultivar Ordinaire showed germination indexes of $8.96 ; 6.52 ; 4.96$ and 4.29 respectively at $30 ; 60 ; 90$ and $120 \mathrm{mM}$ $\mathrm{NaCl}$. The reduction in germination index in this cultivar was significant ( $\mathrm{p} \leq 0.001$ ) from $60 \mathrm{mM}$ $\mathrm{NaCl}$. In cultivar 5-Doigts, the germination indexes were $8.14 ; 8.28 ; 5.91$ and 4.68 respectively at 30 ; $60 ; 90$ and $120 \mathrm{mM} \mathrm{NaCl}$. The reduction in this cultivar was significant ( $\mathrm{p} \leq 0.001$ ) from $90 \mathrm{mM}$ $\mathrm{NaCl}$. The germination indexes of cultivar Acc: Sud 2 were $2.50 ; 0.83 ; 0.00 ; 0.00$ corresponding to a non-significant reduction compared to the control. However, no seed of this cultivar germinated above $60 \mathrm{mM} \mathrm{NaCl}$ during the first three days.

Fig. 4 shows the effect of different $\mathrm{NaCl}$ concentrations on the final germination percentage of the three jute cultivars. In the absence of stress, the final germination percentages were $83.75 \%$; $78.12 \%$ and $55.00 \%$ respectively for cultivars Ordinaire, 5-Doigts and Acc: Sud 2. Ordinaire showed the highest final germination percentage while Acc: Sud 2 exhibited the lowest. The effect of $\mathrm{NaCl}$ caused a reduction in the final germination percentage in all cultivars studied. However, the three cultivars exhibited variable behaviors. Cultivar Ordinaire exhibited final germination percentages of $83.75 \% ; 83.75 \%$; $60.00 \%$ and $60.62 \%$ corresponding to significant reduction ( $\mathrm{p} \leq 0.001$ ) from $90 \mathrm{mM} \mathrm{NaCl}$. In cultivar 5-Doigts, the germination percentages were $75.62 \%$; 79.37\%; $58.75 \%$ and $33.75 \%$ corresponding to significant reduction ( $\mathrm{p} \leq 0.001)$ only at $120 \mathrm{mM} \mathrm{NaCl}$. The final germination percentages of Acc: Sud 2 were 54.37\%; 43.12\%; 30.00 and $10.00 \%$ corresponding to significant reduction ( $\mathrm{p} \leq 0.001$ ) from $90 \mathrm{mM}$ $\mathrm{NaCl}$. Thus, the reduction of final germination percentage by salt stress was less accentuated in cultivar 5-Doigts in comparison with the two other cultivars.

\section{Salt Tolerance Index of cultivars}

The salt tolerance indexes (STI) varied from 0.623 in the cultivar Acc: Sud 2 to 0.859 in the cultivar Ordinaire (Table 2). However, the difference among these indexes is not significant. However, 
this index remains higher for cultivar Ordinaire and lower for cultivar Acc: Sud 2.

\section{Effect of salinity on young plant growth}

Salinity symptoms were characterized by leaf chlorosis associated to necrosis (Fig. 5).

\section{Plant height}

Fig. 6 reveals the reduction of plant growth under salt stress. Salt stress effect resulted in a decrease in plant height growth in the three cultivars but this decrease was significant $(\mathrm{p} \leq 0.05)$ only for cultivar Acc: Sud 2 (Fig. 7). Thus, plant height of cultivar Acc: Sud 2 was more affected by salt stress than that of the two other cultivars which reacted the same way.

\section{Leaf number}

Salt stress effect resulted in a decrease in plant height growth in the three cultivars but this decrease was significant $(\mathrm{p} \leq 0.05)$ for cultivar Acc: Sud 2 from $90 \mathrm{mM} \mathrm{NaCl}$ and only at $120 \mathrm{mM} \mathrm{NaCl}$ for cultivar 5-Doigts (Fig. 8). Thus, leaf number of cultivars Acc: Sud 2 was the most affected by salt stress whereas that of cultivar Ordinaire was the least affected; cultivar 5-Doigts showed an intermediary behavior.

\section{Shoot fresh mass}

Salt stress effect resulted in a decrease in fresh mass growth in the three cultivars but this decrease was significant ( $\mathrm{p} \leq 0.05)$ for cultivar Acc: Sud 2 from $90 \mathrm{mM} \mathrm{NaCl}$ and only at $120 \mathrm{mM} \mathrm{NaCl}$ for cultivar 5-Doigts (Fig. 9). Thus, shoot fresh mass of cultivars Acc: Sud 2 was the most affected by salt stress whereas that of cultivar Ordinaire was the least affected; cultivar 5-Doigts showed an intermediary reaction.

\section{Shoot dry mass}

Salt stress effect resulted in a decrease in dry mass growth in the three jute cultivars but this decrease was not significant for any of the three cultivars (Fig. 10). Thus, shoot dry mass of the three cultivars was affected in the same way.

\section{Roots}

Salt stress induced a non-significant reduction in root growth whatever the growth parameter considered (Table 3). Thus, no root growth parameter was affected by salinity for any of the three jute cultivars.

\section{Salt Tolerance Index (STI) of cultivars}

Results revealed that the difference among STI of the three cultivars was significant only for the parameters CRMFPA and CRMSPR (Table 4). For these two parameters, cultivar Ordinaire exhibited the highest STIs while Acc: Sud 2 cultivar presented the lowest.

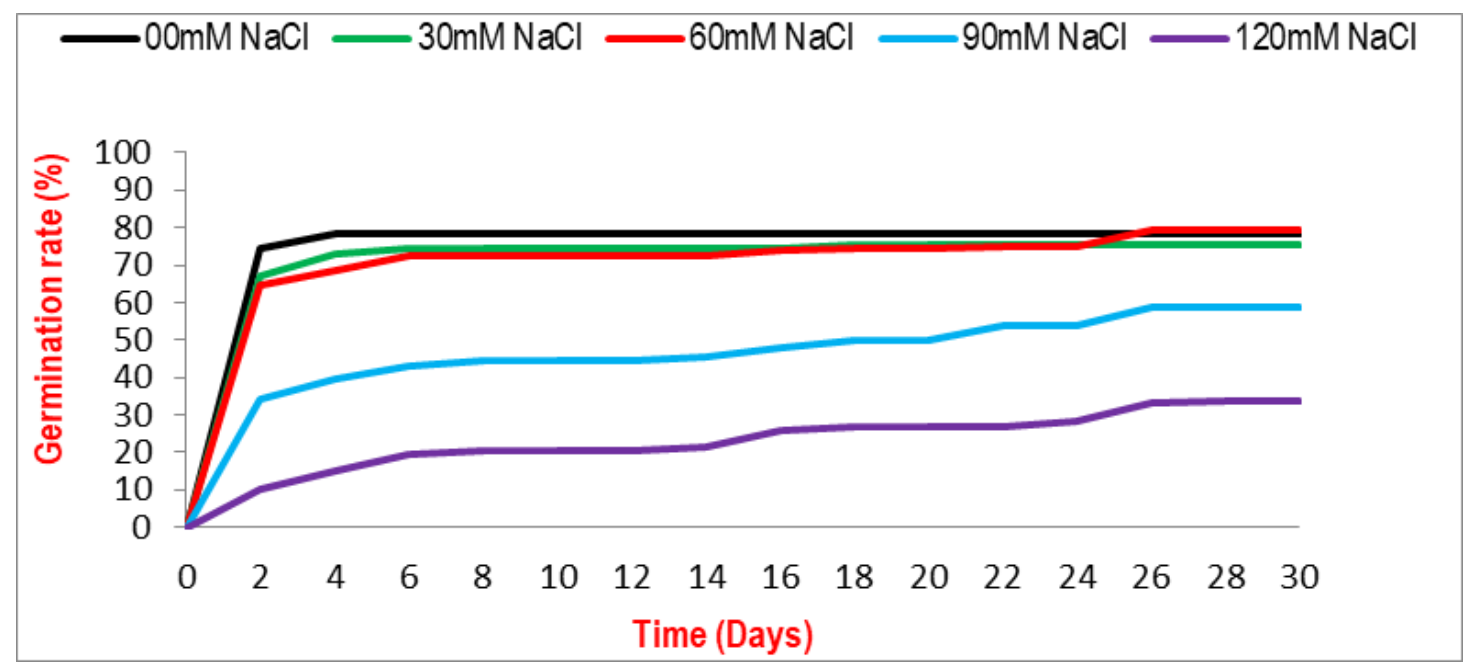

Fig. 1: Rate of germination of tossa jute seeds under saline conditions for cultivar Ordinaire. 


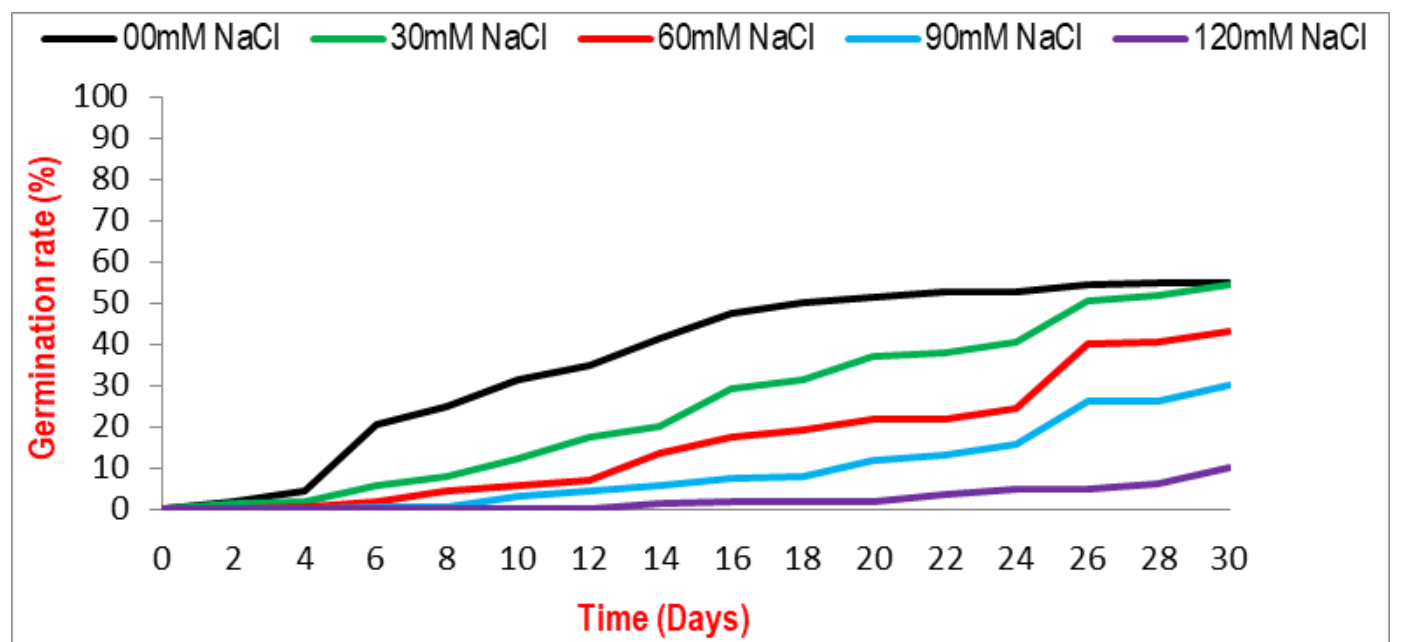

Fig. 2: Rate of germination of tossa jute seeds under saline conditions for cultivar 5 -Doigts.

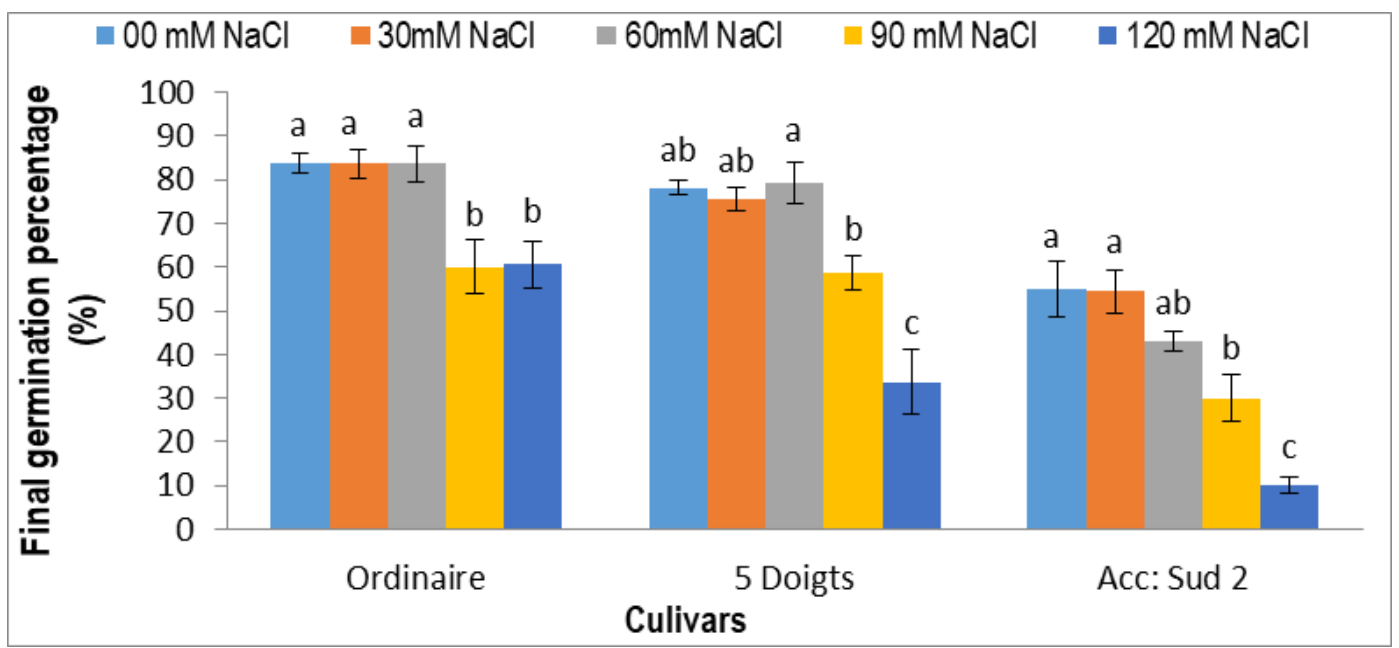

Fig. 3: Rate of germination of tossa jute seeds under saline conditions for cultivar Acc:Sud 2.

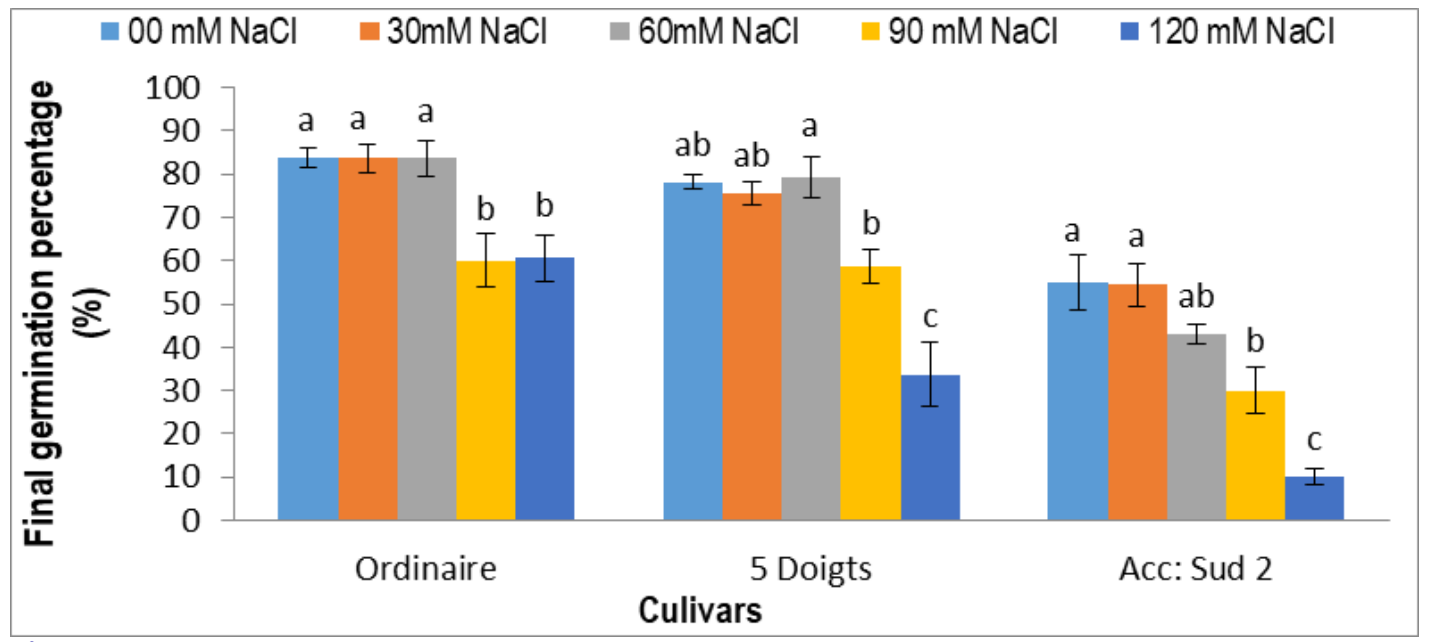

Fig. 4: Effect of different concentrations of $\mathrm{NaCl}$ salinity on final germination percentage of three tossa jute cultivars. Vertical bars are standard error of means of four replications. Means with different letters were significantly different ( $\mathrm{p}<0.05$ or 0.001$)$. 

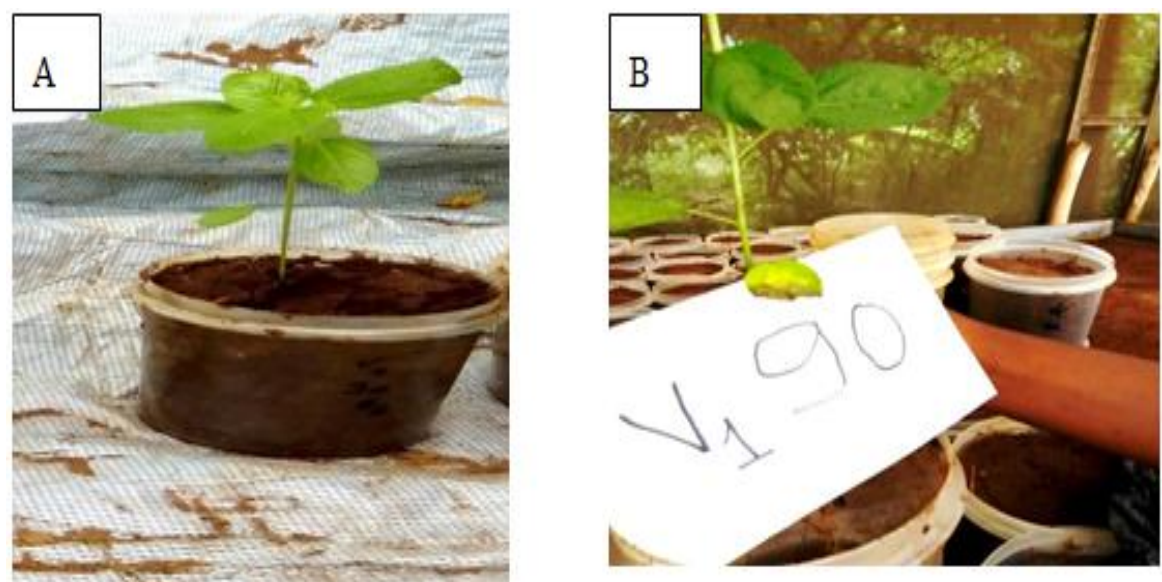

Fig. 5: Salinity symptoms in tossa jute plants (A: Control plants; B: stressed plants).
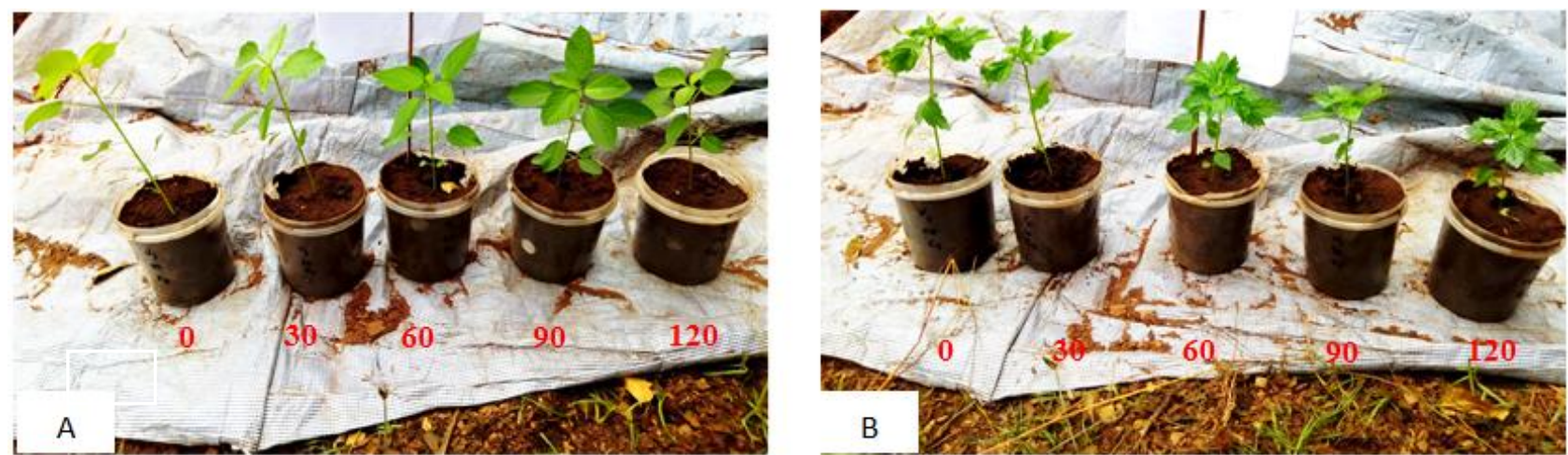

Fig. 6: Plants from cultivar Ordinaire (A) and cultivar 5-Doigts (B) after two weeks under different $\mathrm{NaCl}$ concentrations.

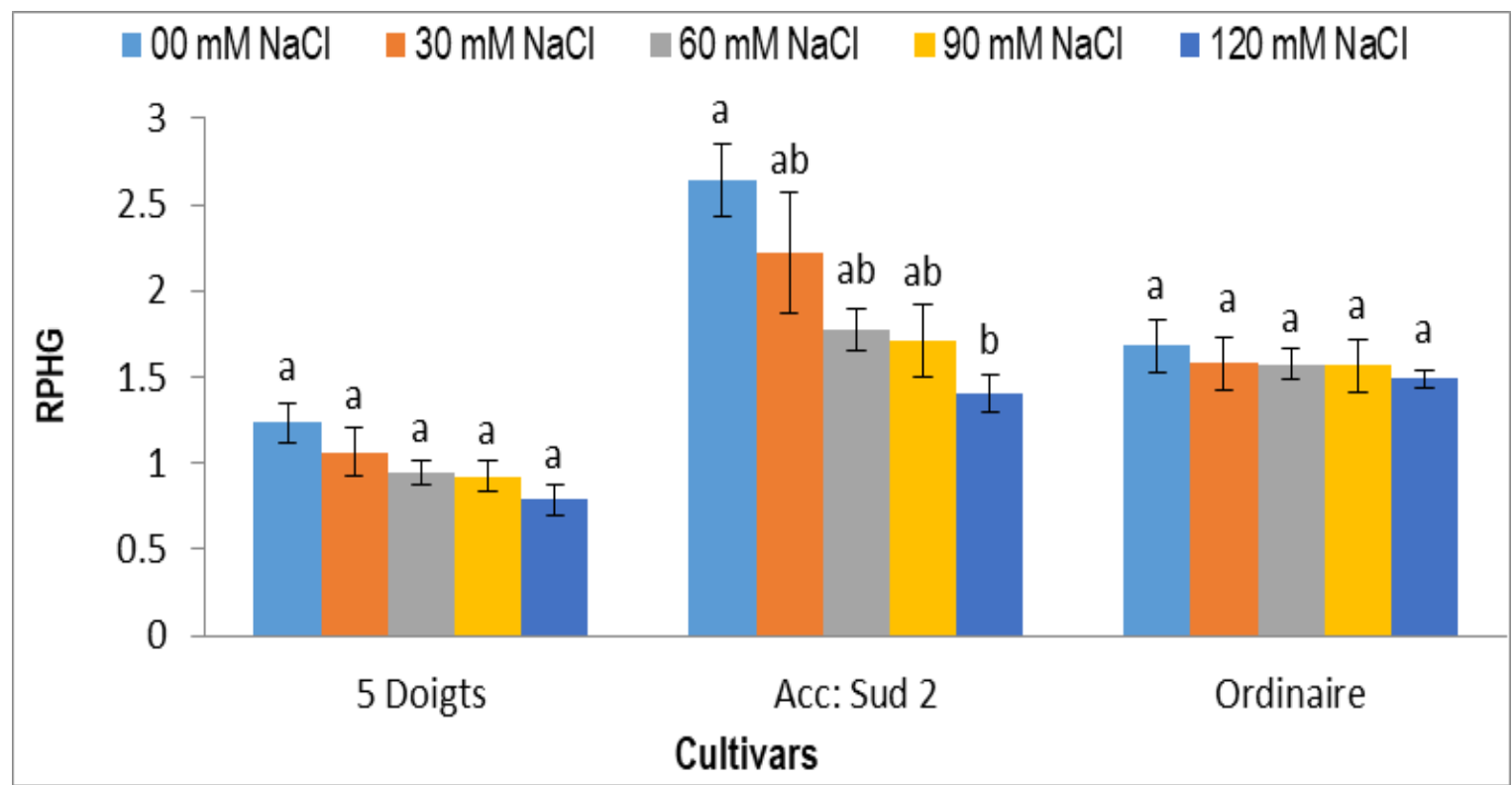

Fig. 7: Plant relative height growth (PRHG) of three tossa jute cultivars under different $\mathrm{NaCl}$ concentrations $(\mathrm{n}=4$; vertical bars are standard errors). Values within cultivar with same letter are not significantly different at $\mathrm{p} \leq 0.05$. 


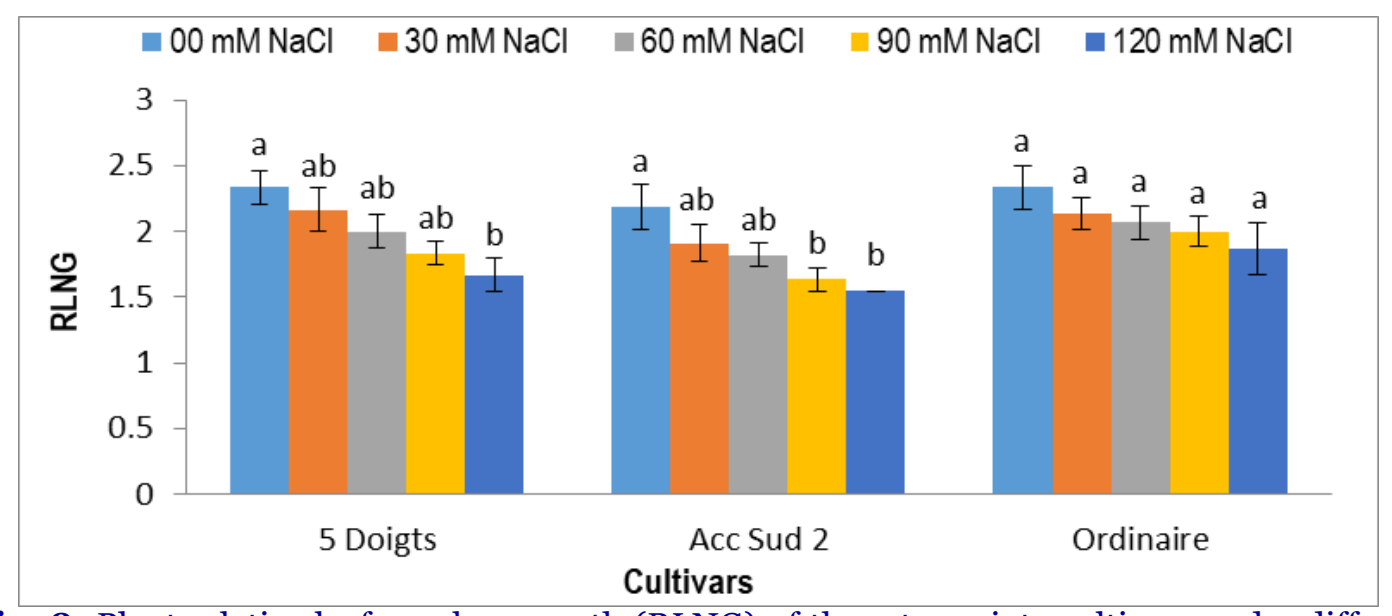

Fig. 8: Plant relative leaf number growth (RLNG) of three tossa jute cultivars under different $\mathrm{NaCl}$ concentrations ( $\mathrm{n}=4$; vertical bars are standard errors). Values within cultivar with same letter are not significantly different at $\mathrm{p} \leq 0.05$.

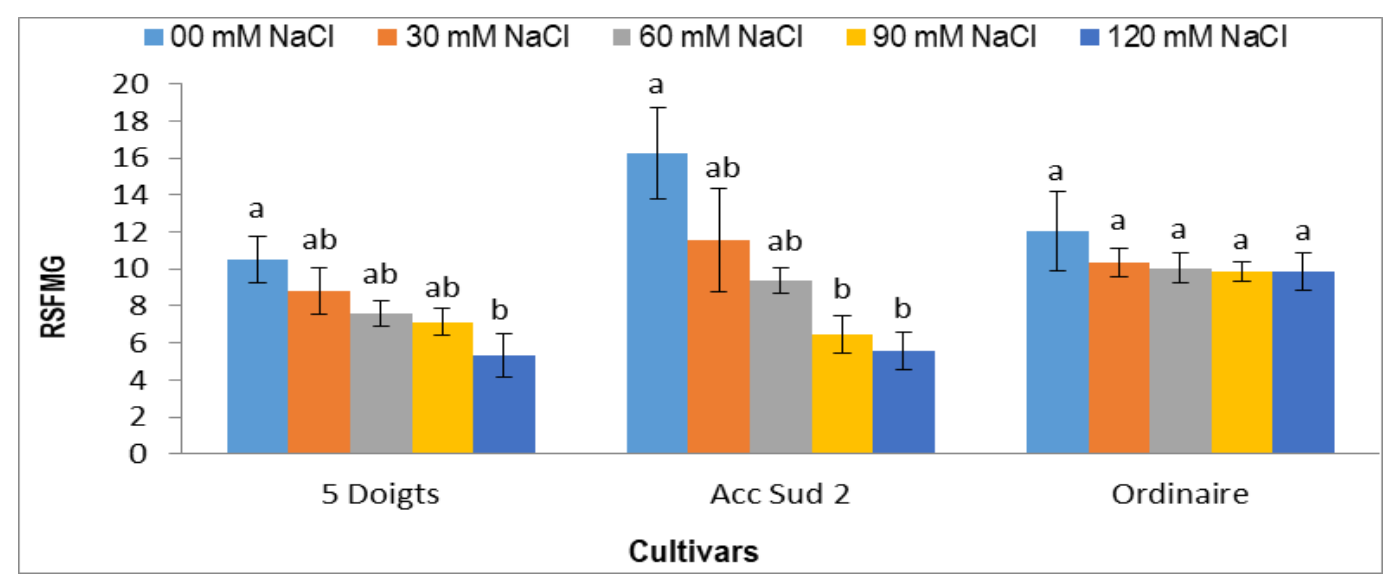

Fig. 9: Relative shoot fresh mass growth (RSFMG) of three tossa jute cultivars under different $\mathrm{NaCl}$ concentrations $(\mathrm{n}=4$; vertical bars are standard errors). Values within cultivar with same letter are not significantly different at $\mathrm{p} \leq 0.05$.

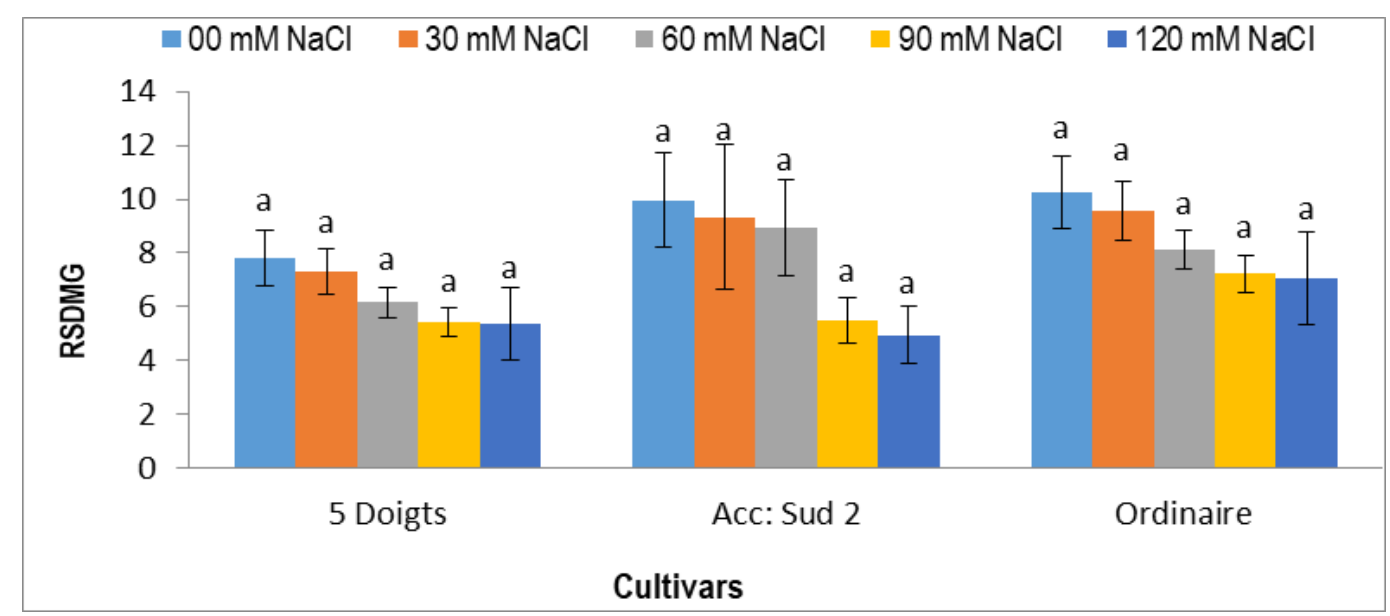

Fig. 10: Relative shoot dry mass growth (RSDMG) of three tossa jute cultivars under different $\mathrm{NaCl}$ concentrations $(\mathrm{n}=4$; vertical bars are standard errors). Values within cultivar with same letter are not significantly different at $\mathrm{p} \leq 0.05$. 
Table 1. Effect of different concentrations of $\mathrm{NaCl}$ salinity on germination index of three tossa jute cultivars.

\begin{tabular}{|c|c|c|c|c|c|}
\hline \multirow{2}{*}{ Cultivars } & \multicolumn{5}{|c|}{ NaCl concentrations (mM) } \\
\hline & $\mathrm{OO}$ & 30 & 60 & 90 & 120 \\
\hline Ordinaire & $8.780 \pm 0.12^{\mathrm{a}}$ & $8.966 \pm 0.28^{\mathrm{a}}$ & $6.528 \pm 0.32^{b}$ & $4.969 \pm 0.07^{c}$ & $4.294 \pm 0.42^{c}$ \\
\hline 5-Doigts & $9.047 \pm 0.13^{\mathrm{a}}$ & $8.148 \pm 0.28^{a}$ & $8.289 \pm 0.33^{\mathrm{a}}$ & $5.915 \pm 0.34^{b}$ & $4.688 \pm 0.35^{b}$ \\
\hline Acc : Sud 2 & $2.500 \pm 1.44^{\mathrm{a}}$ & $2.500 \pm 1.44^{\mathrm{a}}$ & $0.833 \pm 0.83^{\mathrm{a}}$ & $0.000 \pm 0.00^{\mathrm{a}}$ & $0.000 \pm 0.00^{\mathrm{a}}$ \\
\hline
\end{tabular}

Values are means \pm standard errors $(\mathrm{n}=4)$. Means with different letters were significantly different $(\mathrm{P}<0.05)$.

Table 2. Salt tolerance Index of three tossa jute cultivars at germination stage under five $\mathrm{NaCl}$ concentrations (o; 30; 60.90 and $120 \mathrm{mM})$.

\begin{tabular}{llll}
\hline & Cultivars & \\
\cline { 2 - 3 } & Ordinaire & 5-Doigts & Acc: Sud 2 \\
\hline STI & $0.859 \pm 0.04^{\mathrm{a}}$ & $0.791 \pm 0.06^{\mathrm{a}}$ & $0.623 \pm 0.09^{\mathrm{a}}$ \\
\hline Val & & $0.05)$
\end{tabular}

Values are means \pm standard errors $(\mathrm{n}=4)$. Means with different letters were significantly different $(\mathrm{P}<0.05)$.

Table 3: Effect of different $\mathrm{NaCl}$ concentrations $(0,30 ; 60 ; 90$ and $120 \mathrm{mM})$ on root growth of three jute cultivars after two weeks of stress.

\begin{tabular}{lllllll}
\hline \multirow{2}{*}{ Cultivars } & Growth & \multicolumn{6}{c}{ Concentrations de NaCl (mM) } \\
\cline { 3 - 6 } & parameters & \multicolumn{1}{c}{$\mathbf{0}$} & $\mathbf{3 0}$ & $\mathbf{6 0}$ & $\mathbf{9 0}$ & $\mathbf{1 2 0}$ \\
\hline \multirow{3}{*}{5 Doigts } & RRLG & $2.17 \pm 0.55^{\mathrm{a}}$ & $2.05 \pm 0.65^{\mathrm{a}}$ & $1.93 \pm 0.80^{\mathrm{a}}$ & $1.91 \pm 0.34^{\mathrm{a}}$ & $1.80 \pm 0.43^{\mathrm{a}}$ \\
& RRFMG & $7.71 \pm 1.15^{\mathrm{a}}$ & $6.05 \pm 0.43^{\mathrm{a}}$ & $5.67 \pm 1.36^{\mathrm{a}}$ & $4.68 \pm 0.65^{\mathrm{a}}$ & $3.93 \pm 0.47^{\mathrm{a}}$ \\
& RRSDMG & $3.58 \pm 0.76^{\mathrm{a}}$ & $2.33 \pm 0.28^{\mathrm{a}}$ & $2.04 \pm 0.57^{\mathrm{a}}$ & $1.92 \pm 0.32^{\mathrm{a}}$ & $1.62 \pm 0.29^{\mathrm{a}}$ \\
& RRLG & $1.48 \pm 0.31^{\mathrm{a}}$ : Sud 2 & $1.38 \pm 0.50^{\mathrm{a}}$ & $1.19 \pm 0.33^{\mathrm{a}}$ & $1.07 \pm 0.22^{\mathrm{a}}$ & $1.07 \pm 0.31^{\mathrm{a}}$ \\
& RRFMG & $20.69 \pm 3.66^{\mathrm{a}}$ & $16.28 \pm 4.86^{\mathrm{a}}$ & $12.17 \pm 1.45^{\mathrm{a}}$ & $9.84 \pm 2.40^{\mathrm{a}}$ & $7.69 \pm 1.80^{\mathrm{a}}$ \\
& RRSDMG & $17.12 \pm 9.08^{\mathrm{a}}$ & $7.75 \pm 2.80^{\mathrm{a}}$ & $5.37 \pm 1.76^{\mathrm{a}}$ & $4.37 \pm 1.44^{\mathrm{a}}$ & $3.75 \pm 0.94^{\mathrm{a}}$ \\
& RRLG & $4.92 \pm 0.63^{\mathrm{a}}$ & $4.53 \pm 0.36^{\mathrm{a}}$ & $4.48 \pm 0.63^{\mathrm{a}}$ & $3.85 \pm 0.59^{\mathrm{a}}$ & $3.85 \pm 0.64^{\mathrm{a}}$ \\
& RRFMG & $14.95 \pm 3.24^{\mathrm{a}}$ & $11.02 \pm 0.94^{\mathrm{a}}$ & $10.87 \pm 2.16^{\mathrm{a}}$ & $10.67 \pm 1.07^{\mathrm{a}}$ & $10.42 \pm 0.57^{\mathrm{a}}$ \\
& RRSDMG & $8.17 \pm 1.53^{\mathrm{a}}$ & $5.67 \pm 0.56^{\mathrm{a}}$ & $5.08 \pm 1.15^{\mathrm{a}}$ & $4.83 \pm 0.64^{\mathrm{a}}$ & $4.25 \pm 0.59^{\mathrm{a}}$ \\
\hline
\end{tabular}

Values are means \pm standard errors $(\mathrm{n}=4)$. Means with different letters were significantly different $(\mathrm{P}<0.05)$.

Table 4. Salt Tolerance Index (STI) of three tossa jute cultivars after two weeks under salt stress.

\begin{tabular}{|c|c|c|c|c|c|c|c|}
\hline Cultivars & CRHP & CRNF & CRMFPA & CRMSPA & CRLR & CRMFPR & CRIMSPR \\
\hline 5 Doigts & $0.76 \pm 0.06^{a}$ & $0.83 \pm 0.04^{a}$ & $0.67 \pm 0.04^{\mathrm{ab}}$ & $0.76 \pm 0.05^{a}$ & $0.93 \pm 0.15^{a}$ & $0.64 \pm 0.04^{a}$ & $0.5^{2} \pm 0.05^{a}$ \\
\hline Acc: Sud 2 & $0.68 \pm 0.05^{\mathrm{a}}$ & $0.80 \pm 0.04^{\mathrm{a}}$ & $0.53 \pm 0.07^{b}$ & $0.78 \pm 0.14^{\mathrm{a}}$ & $0.85 \pm 0.16^{\mathrm{a}}$ & $0.60 \pm 0.11^{\mathrm{a}}$ & $0.26 \pm 0.05^{b}$ \\
\hline Ordinaire & $0.68 \pm 0.03^{\mathrm{a}}$ & $0.87 \pm 0.04^{\mathrm{a}}$ & $0.85 \pm 0.08^{a}$ & $0.77 \pm 0.05^{\mathrm{a}}$ & $0.84 \pm 0.07^{a}$ & $0.73 \pm 0.09^{a}$ & $0.58 \pm 0.05^{a}$ \\
\hline
\end{tabular}

Values within columns with different letters are significantly different at $\mathrm{p} \leq 0.05$.

\section{Discussion}

\section{Effect of salinity on germination}

Cultivar 5-Doigts reached its maximum germination by day 4 and cultivar Ordinaire at day 24 in the absence of stress. This indicates that the germination rate was faster in cultivar 5 -Doigts. At the end of the experiment, cultivar Ordinaire showed the highest percentage of germination while Acc: Sud 2 showed the lowest. These results revealed a variability in germination capacity of seeds of the three cultivars and cultivar Ordinaire has the greatest germination capacity and Acc: Sud 2 the weakest. Maximum germination in the presence of stress was obtained from the fourteenth $\left(14^{\text {th }}\right)$ day for cultivar Ordinaire, the twenty-sixth $\left(26^{\text {th }}\right)$ day for 5 -Doigts and at the thirtieth $\left(30^{\text {th }}\right)$ day for Acc: Sud 2. These results showed that the effect of $\mathrm{NaCl}$ on the kinetics of germination depends on the cultivar and that within the limits of the concentrations and cultivars tested, a study on the effect of salinity on the germination of tossa jute cultivars must be 
made at least over thirty days.

Seed germination of all cultivars was delayed by the effect of salinity more at the start of germination. Similar results were observed in several species such as watermelon (Hend et al., 2007), melon (Botia et al., 1998), chili (Kpinkoun et al., 2018), tomato (Kinsou et al., 2019), lettuce (Grahn et al., 2015) and cucumber (Zhang et al., 2014). In other jute cultivar, it was reported that salt stress delayed the initiation process and decreased significantly kinetics and rate of germination, which were severely limited at 9 and 10 g.l ${ }^{-1} \mathrm{NaCl}$ (Ben Yakoub et al., 2019). According to Ghrib et al. (2011), this delay could be due to the alteration of enzymes and hormones which are found in the seed whereas for Ben Miled et al. (1986), this could be explained by the time required for the seed to set up mechanisms allowing it to adjust its internal osmotic pressure. Further studies are needed to determine the exact cause of this germination delay. This delay in germination was reflected in the reduction of the germination index by salinity. Similar results have been reported in several species such as amaranth (Wouyou et al., 2016), chilli (Kpinkoun et al., 2018) and cabbage (Gouveitcha et al., 2020). Our results showed that the reduction in the germination index is less noted in the cultivar Acc: Sud 2 compared to the two other cultivars but is more noted in the cultivar Ordinaire. The effect of $\mathrm{NaCl}$ also resulted in a reduction in the final germination percentage in the cultivars tested. The reduction in the final germination percentage by salt stress has been reported in several species including watermelon (Hend et al., 2007), cabbage (Gouveitcha et al., 2020), chilli (Kpinkoun et al., 2018), peppers (Ertan et al., 2006), tomato (Kinsou et al., 2019) and other tossa jute genotype (Ben Yakoub et al., 2019). This reduction was more noted in cultivar Acc: Sud 2 and less noted in Ordinaire. However, the difference among the salt tolerance indices of the three cultivars was not significant indicating that the three cultivars are very similar in terms of level of resistance to salinity.

Our results indicate that the reaction of cultivars with respect to salinity at the germination stage depends on the criterion used. Considering the germination index, the cultivar Acc: Sud 2 appears to be the least affected and the Ordinaire cultivar the most affected. Considering the final germination percentage, cultivar 5-Doigts was the least affected and the Acc: Sud 2 cultivar the most affected. Since the final germination percentage covers the entire duration of the experiment while the germination index only takes into account the first three days, the final germination percentage appears to be the most accurate parameter to assess the response of cultivars with respect to salinity. Thus, cultivar 5-Doigts appears to be the most resistant to salinity at the germination stage and Acc: Sud 2 the most sensitive; cultivar Ordinaire exhibits intermediary behavior.

\section{Effect of salt stress on the growth of young plants}

The effect of salinity was reflected in chlorosis and necrosis at the tips of jute plants leaves. Similar results have been reported by Ibn MaaouiaHouimli et al. (2011) on three pepper cultivars, and by Gandonou et al. (2011) on sugar cane.

The increasing salt concentrations gradually inhibited the growth of the aerial part and roots of the young plants of all three cultivars. Our results corroborated those of Ghosh et al. (2013) and Ben Yakoub et al. (2019) who reported that the growth of jute plants was inhibited by salt stress. Similar results were also reported in other vegetables such as amaranth (Wouyou et al., 2017); chili (Kpinkoun et al., 2019) and tomato (Kinsou et al. 2020). The results also revealed that from the seven growth parameters studied, three of the four parameters of the aerial part were significantly affected while none of the three roots growth parameters evaluated were significantly affected by the concentrations of $\mathrm{NaCl}$ used. These results indicated that the aerial part is more sensitive to salinity than roots. These results corroborated those of Kpinkoun et al. (2019) in chilli who found that the aerial part is more affected by salinity than roots. Similar results have been reported in amaranth (Wouyou et al., 2017). On the other hand, an opposite trend has been reported in vitis vinifera (Hamrouni et al., 2011) where roots has been more affected by salinity than the aerial part. These observations indicated that the relative level of salinity sensitivity of aerial part and roots depends on the species.

The decrease in growth of the vegetative system 
observed in plants can be explained by the fact that the $\mathrm{NaCl}$ acts by increasing osmotic pressure of the medium, which induced a reduction of water absorption by the root system (Ibn MaaouiaHouimli et al. (2011). Indeed, this developmental delay allows the plant to accumulate energy and resources to alleviate stress before the imbalance in the body increases to a point where the damage is irreversible. Furthermore, it has been reported that the reduction in plant growth, in particular in the accumulation of biomass, could be the consequence of water stress resulting from a decrease in the external osmotic potential and / or the accumulation of toxic ions (Odjegba et al., 2012). Further studies are needed to determine which of these physiological factors are preponderant in the tossa jute response to salinity.

It is well known in plants that there is substantial variation in resistance to salinity among cultivars of the same species (Lutts et al., 1995; Bhattacharjee, 2008; Gandonou et al., 2012; Wouyou et al., 2017). Our data confirm that this is also the case for tossa jute since a significant difference was observed among the salt tolerance indexes (STI) of cultivars at young plant stage. Indeed, the results revealed a significant difference among the STI of the three cultivars for the parameters shoot fresh mass and root dry mass. For all two parameters, cultivar Ordinaire exhibited the highest STI and therefore appears to be the most salt resistant cultivar. In contrast cultivar Acc: Sud 2, which has the lowest STI for these two parameters, appears to be the most salt sensitive; cultivar 5-Doigts has an intermediary salt-resistance. These data revealed a variability in salt-resistance of the three jute cultivars tested at young plant stage as reported for other jute cultivars (Ghosh et al., 2013).

In several species, it has been reported that a cultivar resistant to the germination stage may appear to be susceptible to the growth stage of young plants and vice versa. This trend has been reported in sugar cane (Gandonou and Skali Senhaji, 2015), amaranth (Wouyou, 2017), wheat (Sahoo et al., 2018) and tomato (Kinsou et al., 2020). Our study revealed that cultivar 5 -Doigts which was the most salt resistant at germination stage appeared as an intermediary cultivar at young plant stage. In the same way, cultivar Ordinaire which was the most salt resistant at young plant stage appeared as an intermediary cultivar at germination stage. Thus, salt resistance of a given tossa jute cultivar at germination stage does not secure its salt resistance at further growth stage. However, cultivar Acc :Sud 2 maintained its status against salt stress either at germination stage or at young plant stage. These observations indicate that the responses of cultivars / varieties of the same species to salinity at different developmental stages depend not only on the species but also on the cultivars / varieties considered.

\section{Conclusion}

Salinity negatively affected seed germination and plant growth in the three tossa jute cultivars evaluated with a difference among them. Cultivar 5-Doigts appeared as the most resistant to salt stress at germination stage; whereas cultivar Ordinaire followed by 5 -Doigts was the most salt resistant at young plant stage. Thus, for the first time, we have demonstrated that there is variability between the levels of salt resistance of the two local cultivars of tossa jute from Benin. Cultivar Ordinaire may be recommended to growers in salt affected areas while growers in other areas may produce any of the three cultivars.

\section{References}

Ahmadi, M., Zamani, S., Salehpoor, H., Zahra, R.M., 2016. Effect of salinity stress on germination and heterotrophic growth of wild okra (Corchorus olitorius L.) seeds. J. Res. Ecol. 4(1), 94-100.

Almansouri, M., Kinet, J.M., Lutts, S., 2001. Effect of salt and osmotic stresses on germination in durum wheat (Triticum durum Desf.). Plant Soil. 231, 243-254.

Ashraf, M., Harris, P.J.C., 2004. Potential biochemical indicators of salinity tolerance in plants. Plant Sci. 166, 3-16.

Ben Miled, D., Bousaid, M., Adblkeffi, A., 1986. Colloque sur les végétaux en milieu aride. Djerba 8- 10 sept. Fac. Sci. de Tunis ept. ACCTT (1986).

Ben Naceur, M., Rahmoune, C., Sdiri, H., Meddahi, M.L., Selmi, M., 2001. Effet du stress salin sur la germination, la croissance et la production en grains de quelques variétés maghrébines de blé. Sécheresse. 12, 167-174. 
Ben yakoub, A.R., Tlahig, S., Ferchichi, A., 2019. Germination, growth, photosynthesis, and osmotic adjustment of tossa jute (Corchorus olitrius L.) seeds under saline irrigation. Pol. J. Environ. Stud. 28(2), 935-942.

Bhattacharjee, S., Triadime, F., 2008. Triadimef on pretreatment protects newly assembled membrane system and causes up-regulation of stress proteins in salinity stressed Amaranthus lividus L. during early germination. J. Environ. Biol. 29(5), 805-810.

Botia, P., Carvagal, M., Cerda, A., Martinez, V., 1998. Response of eight Cucumis melo cultivars to salinity during germination and early vegetative growth. Agronomie 18, 503-513.

Chukwu, L.O., Okpe, H.A., 2006. Differential response of Tilapia guineensis fingerlings to inorganic fertilizer under various salinity regimes. J. Environ. Biol. 27, 687-690.

Déguénon, E., 2018. Communication personnelle évoquée le mercredi 30 mai 2018 lors du Forum des jeunes chercheurs sur la Physiologie Végétale et ses applications au service du développement de l'agriculture : Cas de l'igname et des cultures maraîchères, Université d'Abomey-Calavi, Bénin.

Edmonds, J.M., 1990. Herbarium survey of African Corchorus species. Systematic and Ecogeographic Studies on Crop Genepools 4. International Board for Plant Genetic Resources, Rome, Italy.

Ertan, Y., Ismail, G., 2006. Salt Tolerance of Pepper Cultivars during Germination and Seedling Growth. Turk. J. Agric. For. 30, 347353 .

Gandonou, C.B., Ahanhanzo, C., Agbangla, C., Errabii, T., Idaomar, M., Abrini, J., Skali Senhaji, N., 2011. NaCl effect on in vitro sugarcane bud emergency. Afr. J. Biotechnol. 10(4), 539-544.

Gandonou, C.B., Gnancadja, S.L., Abrini, J., Skali Senhaji, N., 2012. Salinity tolerance of some sugarcane (Saccharum sp.) cultivars in hydroponic medium. Int. Sugar J. 114(1359),190-196.

Gandonou, G.C.B., Skali Senhaji, N., 2015. Sugarcane (Saccharum sp.) salt tolerance at various developmental levels. In: Chakraborty U, Chakraborty B, Editors. Abiotic Stresses in Crop Plants. CABI Publishing, United Kingdom, ISBN-13, 978-1-78064-373-1.

Ghosh, P.K., Phumichai, T., Sreewongchai, T.,
Nakasathien, S., halermpol Phumichai, C., 2013. Evaluation of salt tolerance of jute (Corchorus spp.) genotypes in hydroponics using physiological parameters. Asian J. Plant Sci. 12, 149-158.

Ghrib, C.D., Gharbi, F., Rejeb, S., Khoudja, L., Rejeb, M.N., 2011. Tolérance à la salinité de trois espèces d'Eucalyptus aux stades germinatif et plantule. Eur. J. Sci. Res. 50 (2), $208-217$.

Gouveitcha, M.B.G., Montcho Hambada, K.D., Zanklan, A.S., Wouyou, A.D., Gandonou, G.C.B., 2020. Évaluation de la résistance à la salinité chez trois variétés de chou (Brassica oleracea) cultivées au Bénin au stade germination. J. Appl. Biosci. 146, 15025-15039.

Grahn, C.M., Hillier, B., Benedict, C., Miles, C., 2015. Screening USDA Lettuce (lactua Sativa L.) Germplasm for ability to germinate under cold conditions. Hort. Sci. 5O(8), 1155-1159.

Hadas, A., 2004. Seedbed Preparation: The Soil Physical Environment of Germinating Seeds. In: Handbook of Seed Physiology: Applications to Agriculture, Benech-Arnold, R.L. and R.A. Sanchez (Eds.). Food Product Press, New York, ISSN: 1560229292, pp 3-49.

Hamrouni, L., Hanana, M., Abdelly C., Ghorbel, A., 2011. Exclusion du chlorure et inclusion du sodium: deux mécanismes concomitants de tolérance à la salinité chez la vigne sauvage Vitis vinifera subsp. sylvestris (var. 'Séjnène'). Biotechnol. Agron. Soc. Environ. 15(3), 387400.

Hend, A., Saloua, R., Hager, J., Hassen, N., Mohamed, N.R., 2007. Effet du chlorure de sodium sur la germination des graines de trois variétés de pastèque (Citrullus lanatus L.). Sécheresse. 18(1), 51-55

Hussain, A., Khan, Z.I., Ashraf, M., Rashid, H.M., Akhtar, M.S., 2004. Effect of salt stress on some growth Attributes of Sugarcane Cultivars CP-77-400 and COJ-84. International Journal of Agriculture and Biology. 6 (1), 188-191.

Ibn Maaouia-Houimli, S., Denden, M., DridiMouhandes, B., Ben Mansour-gueddes, S., 2011. Caractéristiques de la croissance et de la production en fruits chez trois varieties de piment (Capsicum anmuum) sous stress salin. Tropicultura. 29 (2), 75-81.

Islam, M.T., Begum, M.B., and Islam, M.O., 2011. Screening of jute mutants for salinity tolerance. Int. J. Sustain. Crop Prod. 6, 6-11. 
Kahane, R., Temple, L., Brat, P., Hubert, D., 2005. Les légumes feuilles des pays tropicaux : diversité, richesse économique et valeur santé dans un contexte très fragile, Col. Ang. 3-14.

Kaya, C., AK, B.E., Higgs, D., 2003. Response of salt-stressed strawberry plants to supplementary calcium nitrate and/or potassium nitrate. J. Plant. Nutr. 26(3), 543560.

Khan, M.A., Gulzar, S., 2003. Germination Responses of Sporobolus ioclados: A Saline Desert Grass. J. Arid Environ. 53, 387-394.

Khandker, S., Begum, H., Alam, A.K.M.M., Alam, M.M., Ahmad, S.A., Iqbal, M.S., Islam, M.M., 1992. Salinity effect on germination and seedling growth of seeds of different species of jute (Corchorus spp.) and allied fibre (Hibiscus spp). Bangladesh J. Jute Fib. Res. 17, 85-91.

Kinsou, E., Mensah, A., Montcho Hambada, D.K., Zanklan, A.S., Wouyou, A., Kpinkoun, K.J., Assogba Komlan, F., Gandonou, C.B., 2020. Response of seven tomato (Lycopersicon esculentum Mill.) cultivars produced in Benin to salinity stress at young plant stage. Int. J. Curr. Res. Biosci. Plant Biol. 7(8), 1-11.

Kinsou, E., Montcho, D., Zanklan, S.A., Kpinkoun, J.K., Komlan, F.A., Mensah, A.C.G., Gandonou, C.B., 2019. Salt resistance of tomato (Lycopersicon esculentum Mill.) cultivars produced in Benin at germination stage. Int. J. Plant Soil Sci. 28(2), 1-12.

Kpinkoun, J.K., Zanklan, S.A., Assogba Komlan, F., Mensah, A.C.G., Montcho, D., Kinsou, E., Gandonou, C.B., 2019. Évaluation de la résistance à la salinité au stade jeune plant de quelques cultivars de piment (Capsicum spp.) du Benin. J. Appl. Biosci. 133, 13561-13573.

Kpinkoun, J.K., Zanklan, S.A., Montcho, D., Kinsou, E., Komlan, F.A., Mensah, A.C.G., Wouyou, A.D., Gandonou, C.B., 2018. Response of chili pepper (Capsicum spp.) cultivars cultivated in Benin to salt stress at germination stage. Int. J. Plant Soil Sci. 23(3), 1-11.

Lakra, N., Mishra, S.N., Singh, D.B., Pushpa, C.T., 2006. Exogenous putrescine effect on cation concentration in leaf of Brassica juncea seedlings subjected to $\mathrm{Cd}$ and $\mathrm{Pb}$ along with salinity stress. J. Environ. Biol. 27, 263-269.

Lutts Kinet, J.M., Bouharmont, J., 1995. Changes in plant response to $\mathrm{NaCl}$ durning development of rice (Oryza sativa L.) varieties differing in salinity resistance. J. Exp. Bot. 46, 276- 282.

Manchanda, G., Garg, N., 2008. Salinity and its effects on the functional biology of legumes. Acta Physiologiae. Plantarum. 30 (5), 595- 618.

Mermoud, A., 2006. Cours de physique du sol : Maîtrise de la salinité des sols. Ecole polytechnique fédérale de Lausanne. $23 \mathrm{p}$.

Naik, M.R., Barman, D., Maruthi, R.T., Mandal, U. K., Kundu, D. K., 2015. Screening of tossa jute (Corchorus olitorius) varieties against salt stress. Int. Quart. J. Environ. Sci. 9(3-4), 815819

Odjegba, V.J., Chukwunwik, I. C., 2012. Physiological responses of Amaranthus hybridus L. under salinity stress, Ind. J. Innov. Dev . 1 (10), 742-748.

Orobiyi, A., Dansi, A., Assogba, P., Loko, L.Y., Dansi, M., Vodouhè, R., Akouègninou, A., Sanni, A., 2013. Chili (Capsicum annuum L.) in southern Benin: production constraints, varietal diversity, preference criteria and participatory evaluation. Int. Res. J. Agric. Sci. Soil Sci. 3(4), 107-120.

Sahoo, S., Baranda, B., Nitesh, S., 2018. Salinity tolerance in wheat. Marumegh. 3(1), 61-65.

Savi, A., 2009. Analyse de la rentabilité financière et de l'efficacité économique de la production du crincrin (Corchorus olitorius) dans la vallée $\mathrm{du}$ Mono. Mémoire pour l'obtention du diplôme d'études Approfondies, FSA/UAC. 93p.

Soro, C.L., Ocho-Anin Atchibri, A.L., Kouadio, A.K.K., Kouamé, C., 2012. Evaluation de la composition nutritionnelle des légumes feuilles J. Appl. Biosci. 51, 3567-3573.

Tabatabaei, S.A., Ranjbar G.H., Anagholi, A., 2012. Evaluation of physiological indices of salinity tolerance in forage Sorghum (Sorghum bicolor) lines. Int. Res. J. Appl. Basic Sci. 3(2), 305-308.

Wouyou, A., 2017. Réponse de l'amarante (Amaranthus cruentus L.) au stress salin: caractérisation de cultivars, mécanisme physiologique de résistance et qualité nutritionnelle des feuilles. Thèse de doctorat, Université d'Abomey-Calavi, Bénin. 156p.

Wouyou, A., Gandonou, C.B., Assogba Komlan, F., Montcho, D., Zanklan, S.A., Lutts, S., Gnancadja, S.L., 2017. Salinity resistance of five amaranth (Amaranthus cruentus) cultivars at young plants stage. Int. J. Plant Soil Sci. 14(3), 1-11. 
Wouyou, A., Gandonou, C.B., Montcho, D., Kpinkoun, J., Kinsou, E., Assogba Komlan, F., Gnancadja, S.L., 2016. Salinity resistance of six amaranth (Amaranthus sp.) cultivars cultivated in Benin at germination stage, Int. J. Plant Soil Sci. 11(3), 1-10.
Zhang, H., Liu, Y., Wen, F., Yao, D., Wang, L., Guo, J., Jiang, M., 2014. A novel rice C2H2-tye Zinc finger protein, $\mathrm{ZFP}_{3} 6$, is a Key player involved in abscisic acid-induced antioxidant defence and oxidative stress tolerance in rice. J. Exp. Bot. 65 (20), 5795-5809.

\section{How to cite this article:}

Loko, B., Hambada Montcho, K. D., Goudjo Mensah, A. C., Gouveitcha, M. B. G., Wouyou, A., Kpinkoun, J. K., Assogba Komlan, F., Gandonou, C. B., 2020. Response of three tossa jute (Corchorus olitorius L.) cultivars produced in Benin to salinity stress at germination and young plant stages. Int. J. Curr. Res. Biosci. Plant Biol. 7(10), 8-21. doi: https://doi.org/10.20546/ijcrbp.2020.710.002 